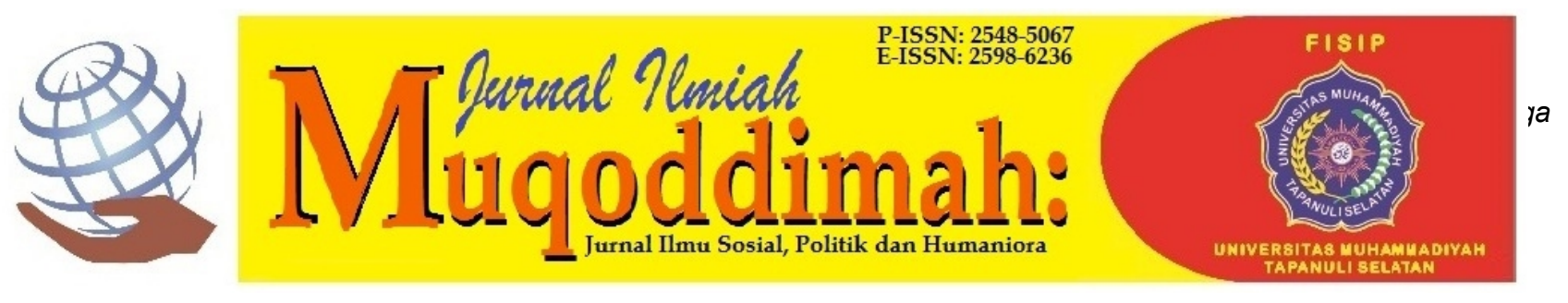

\title{
Analisa Kebijakan Pendidikan Kependudukan: Sekolah Siaga Kependudukan (SSK) Dalam Perspektif Teori AGIL Talcott Parssons
}

\author{
Mohammad Alfin Mahbi Awwaluddin'1), FX. Sri Sadewo') \\ Program Studi Sosiologi, Fakultas IImu Sosial dan Hukum, Universitas Negeri Surabaya \\ Jl. Ketintang No.i8, Ketintang, Kec. Gayungan, Kota Surabaya, Jawa Timur \\ moh.17040564036@mhs.unesa.ac.id \\ Fsadewo@unesa.ac.id
}

\begin{abstract}
Abstrak
Pentingnya pendidikan akan pengendalian penduduk merupakan upaya untuk mengubah perilaku masyarakat untuk merencanakan dan membangun keluarga yang ideal. Sekolah Siaga Kependudukan merupakan sekolah yang mengintegrasikan pendidikan kependudukan dan keluarga berencana ke dalam beberapa mata pelajaran sebagai pengayaan materi pembelajaran, terdapat pojok kependudukan di dalamnya. Penelitian ini bertujuan untuk mengidentifikasi pelaksanaan pendidikan kependudukan melalui Sekolah Siaga Kependudukan dalam perspektif AGIL Talcott Parsons, penelitian ini menggunakan pendekatan kualitatif deskriptif, Penentuan Informan dalam penelitian ini menggunakan teknik Purposive Sampling. Hasil penelitain menunjukkan (1) Adaptation, Sekolah Siaga Kependudukan bukan mata pelajaran baru, materi pelajaran dipertajam yang disesuaikan dengan kondisi kependudukan saat ini, (2) Tujuan dari Sekolah Siaga Kependudukan menumbuhkan peserta didik yang sadar dan tanggung jawab terhadap kondisi kependudukan yang ada disekitarnya, (3) Integrasi pendidikan kependudukan melalui SSK baik dalam kurikulum dan kelembagaan, (4) Latency, membangun nilai dan moral pada individu yang berkarakter di tengah masyarakat, seperti sifat sadar kependudukan, peduli terhadap sesama, dan toleransi antar sesama.
\end{abstract}

Kata Kunci: Pelaksanaan, Pendidikan Kependudukan, Perspektif teori AGIL

\begin{abstract}
The importance of population education is an effort to change people's behavior to plan and build an ideal. Population Alert School is a school that integrates population education and family planning into several subjects as an enrichment for learning material, there is a population corner in it. This study aims to identify the implementation of population education through Population Alert Schools in the perspective of AGIL Talcott Parsons. This study uses a descriptive qualitative approach. Determination of information in this study uses purposive sampling technique. The results of the research show (1) Adaptation, Population Alert Schools are not subjects, sharpened material that is invincible with current demographic conditions, (2) The purpose of Population Alert Schools is to foster students who are aware of and responsible for the surrounding demographic conditions, (3) Integration of population education through SSK in both curriculum and institutions, (4) Latency, building values and morals in individuals with character in society, such as demographic awareness, caring for each other, and tolerance among others.
\end{abstract}

Keywords: Implementation, Population Education, AGIL theory perspective 


\section{PENDAHULUAN}

Kita tahu bahwa penduduk merupakan modal dasar dalam pembangunan, Negara Indonesia memiliki jumlah penduduk terbanyak ke 4 di dunia, Negara Indonesia dapat dikatakan memiliki jumlah penduduk yang sangat banyak, apabila dilihat dari hasil Survei Penduduk Antar Sensus (SUPAS) 2015 jumlah penduduk Indonesia sebanyak 255,18 juta jiwa. penduduk yang besar bisa menjadi aset dalam pembangunan, namun juga bisa menjadi beban dalam pembangunan apabila tidak disertai dengan kualitas yang baik, untuk provinsi Jawa Timur merupakan provinsi dengan penduduk terbanyak nomer 2 di Indonesia setelah provinsi Jawa Barat. jumlah penduduk di Jawa Timur sebanyak 39,5 juta jiwa dengan laju pertumbuhan penduduk $0,76 \%$ per tahun. kondisi penduduk jawa timur di dominasi dengan jumlah usia produktif yang melimpah, kelompok usia 15-64 tahun sebanyak 27,4 juta jiwa atau 69\%(Badan Perencanaan Daerah Jawa Timur, 2019).

Provinsi Jawa Timur sudah melewati dan sedang berada di dalam bonus demografi, keadaan yang menunjukkan jumlah usia produktif presentasenya dua kali penduduk yang tidak produktif, dengan artian rasio ketergantungan atau Dependency Ratiopenduduk produktif bisa menangung usia non produktif(Noor, 2015). Pada saat ini Jawa Timur memiliki keuntungan sebuah modal pembangunan, namun dengan adanya pandemi covid-19 kita tahu bahwa setiap sektor mengalami penurunan. hal tersebut berdampak pada angka pengagguran yang harus segera diatasi, oleh karena itu generasi muda harus memiliki semangat untuk menjadi harapan dalam memanfaatkan bonus demografi. Perbandingan jumlah penduduk yang produktif dengan non produktif membuat saat ini Indonesia terkhusu jawa timur memasuki kondisi yang ideal, hal tersebut sebuat kesempatan untuk meningkatkan prosuktivitas kesejahteraan penduduk (Mayasari \& Husin, 2014).

Tolak ukur dalam pembangunan suatu daerah dapat dikatakan berhasil, bisa dilihat dari Indeks Pembangunan Manusia (IPM), IPM disusun dari kesehatan, pendidikan, dan ekonomi, melihat IPM Kabupaten Gresik sudah dapat dikatakan baik, dengan angka IPM sudah diatas 75\%, angka harapan hidup di Kabupaten Gresik sebesar 72 tahun, artinya peluang harapan hidup rata rata 72 tahun, hal tersebut sudah mencapai target angka harapan hidup di jawa timur yakni 70 tahun. Kemudian indikator pendidikan Kabupaten Gresik sebesar 8,96. Indikator tersebut sudah diatas target provinsi jawa timur sebesar 7,39 , hal tersebut juga berdampak pada pendapatan per Kapita Kabupaten Gresik sudah diatas target dari Provinsi Jawa Timur, artinya pendapatan penduduk per orang di Kabupaten Gresik rata-rata mencapai 12,845,000 per tahun (BPS Indeks Pembangunan Manusia, 2017).

Generasi muda saat ini harus mengerti dan memahami problematik isu kependudukan, pada dasarnya permasalahan kependudukan sangat luas sekali, pentingnya pendidikan akan pengendalian penduduk merupakan upaya untuk mengubah perilaku masyarakat untuk merencanakan dan membangun keluarga yang ideal(Pamungkas, 2017).Masa remaja merupakan masa yang menyenangkan bagi setiap individu, masa ini individu mulai kenal dengan lingkungan sosial yang luas, atau dapat dikatakan masa peralihan dari anak menuju dewasa, remaja seringkali dijadikan sebagai agent of change dalam masyarakat(Mayasari \& Husin, 2014), oleh karena itu Wawasan kependudukan ini tidak hanya diberikan untuk orang dewasa saja, melainkan 
generasi muda harus mendapatkan pendidikan kependudukan, hal tersebut akan berdampak pada kepedulian dan kesadaran mereka tentang isu kependudukan sedini mungkin (Mayasari \& Husin, 2014). Generasi muda yang berkualitas mempunyai peluang sebagai penerus bangsa untuk membangun bangsa yang lebih baik lagi, terbentuknya kepedulian dan kesadaran terhadap isu kependudukan berdampak pada tumbuhnya rasa rasa tanggungjawab untuk ikut serta mencegah dan ikut serta mencari solusi dalam mengatasi permasalahan kependudukan(Mukri, 2018). Program kependudukan sangat penting menyasar generasi muda karena jumlah kuantitas generasi muda sebanyak $30 \%$ dari masyarakat, apabila generasi muda tidak dilibatkan dalam isu kependudukan maka pemerintah memiliki beban yang terlalu besar dalam mengatasi permasalahan kependudukan(Mayasari \& Husin, 2014).Pemerintah Gresik ingin mendorong partisispasi warganya untuk berpatisipasi, karena pada dasarnya permasalahan kependudukan merupakan tugas bersama untuk mengatasi problematika kependudukan di kabupaten Gresik terkhusus memaksimalkan bonus demografi.

Melalui BKKBN dalam rangka mendukung undang-undang nomor 52 tahun2009, tentang perkembangan kependudukan dan pembangunan keluarga, pasal 48 ayat 1 (b) yang berbunyi "Peningkatan kualitas remaja dengan pemberian akses informasi, pendidikan, konseling dan pelayanan tentang kehidupan berkeluarga". Oleh karena itu terbentuklah program Generasi Berencana(Aritonang, 2017). Program Keluarga Berencana dalam lembaga pendidikan berfungsi untuk menyiapkan remaja dalam mematangkan usia pernikahan sebelum berumah tangga(Erlangga, 2019). Sasaran Program KB untuk remaja juga berfungsi memberi informasi mengenai kesehatan reproduksi dengan harapan bisa merencanakan di usia berapa akan menikah dan ingin mempunyai anak berapa sehingga keluarga kecil berkualitas akan terbentuk. BKKBN mencanangkan program GenRe yang dibentuk pada tahun 2009 berfungsi sebagai bentuk peduli terhadap masa depan generasi muda guna tidak terjerumus ke hal-hal negative(Erlangga, 2019). Program GenRe difokuskan untuk pembinaan karakter menjadi generasi yang visioner, program GenRe sendiri memiliki dua pendekatan diantaranya melalui Pusat Informasi Konseling (PIK) digunakan dalam dunia pendidikan, sedangkan Bina Keluarga Remaja (BKR) digunakan dalam masyarakat (Sari \& Indrawadi, 2019).

Maka dari itu dengan adanya Sekolah Siaga Kependudukan diharapkan mampu membentuk karakter remaja akan sadar isu isu yang terjadi dalam penduduk dan ikut serta berpartisipasi dalam menyelesaikan permasalahan kependudukan. Sekolah Siaga Kependudukan merupakan sekolah yang mengintegrasikan pendidikan kependudukan dan keluarga berencana ke dalam beberapa mata pelajaran sebagai pengayaan materi pembelajaran, terdapat pojok kependudukan di dalamnya, dengan harapan sebagai salah satu sumber belajar peserta didik untuk pembentukan generasi berencana(Yulianti, 2017).

Penelitian terdahulu yang relevan terkait dengan tema penelitian diantaranya penelitian yang dilakukan oleh Sari dan Indrawadi, penelitian tersebut bertujuan mengidentifikasi pelaksanaan program GenRe di Kota Padang, hasil penelitian tersebut menunjukkan bahwa pembentukan karakter remaja dilakukan melalui dua pendekatan yaitu, pendekarana secara tidak langsung melalui keluarga (orang tua) dan melalui pendekatan secara langsung melalui lembaga sekolah.Namun pembentukan karakter 
melalui program GenRe di Kota Padang belum terlaksana secara maksimal, hal tersebut disebabkan tiga faktor, diantyaranya 1) Operasional Waktu, 2) Pendanaan, 3) Peran Duta GenRe. Program GenRe yang dilakukan oleh Duta GenRe menuai tanggapan yang bervariasi, mulai tanggapan yang bersifat positif, seperti partisipasi masyarakat dalam kegiatan yang dilakukan oleh Duta GenRe di dalam program Kampung KB, Dilain sisi juga mendapatkan tanggapan yang negatif, adanya masyarakat yang beranggapa umur dan pengetahuan mereka maish rendah dan belum memiliki pengalaman (Sari \& Indrawadi, 2019).

Penelitian selanjutnya dilakukan oleh Susanti, penelitian tersebut bertujuan mengidentifikasi strategi komunikasi yang dilakukan oleh BKKBN daerah Yogyakarta untuk mensosialisasikan program GenRe, hasil penelitian tersebut menunjukkan bahwa sosialisai yang dilakukan oleh BKKBN dalam program GenRe melalui lembaga pendidikan, seperti Pemilihan Duta Mahasiswa GenRe, GenRe Goes To Scool, terdapatnya event perlombaan poster GenRe, Lomba Komedi GenRe juga sebagai cara yang dilakukan BKKBN dalam sosialisasi program GenRe. Selain itu BKKBN menggunakan media masa dalam mensosialisasikan program GenRe, melalui media internet (Blog, facebook dan twitter), TV daerah serta iklan layanan masyarakat. BKKBN DIY juga membentuk Pusat Informasi Konseling Remaja/Mahasiswa agar lebih dekat dengan remaja dan mahasiswa (Susanti, 2015).

Penelitihan terdahulu berikutnya dilakukan oleh Utami, penelitihan tersebut menggunakan studi komparatif untuk melihat sikap remaja setelah dapat informasi dari BKKBN mengenai penyuluhan program GenRe. Ada beberapa hal yang harus di ditingkatkan dalam penyuluhan GenRe yakni kuantitas penyuluhan di jadwalkan lebih sering lagi, seklaigus kualitas penyuluh juga harus ditingkatkan lagi melalui pelatihanpelatihan mengenai penyuluhan (Utami, 2015).

Kajian yang dilakukan oleh Fernandes membahas mengenai respon sekolah terhadap kebijakan pendidikan inklusif yang terjadi di Kota Padang, tujuan dari penelitian tersebut ingin mengidentifikasi respon sekolah terhadap instruksi yang diberikan oleh pemerintahan Kota Padang, perlunya adaptasi yang dilakukan pihak sekolah, adaptasi tersebut muali dari tenaga pendidik, sarana prasarana dalam menunjang kebijakan pendidikan inklusif, oleh karena itu respon yang dilakukan sekolah cenderung melakukan pemeliharaan system dengan menjaga keseimbangan dengan system lainya(Fernandes, 2017).

Berawal dari berbagai penelitian sebelumnya tentang pendidikan kependudukan yang mengkaji tenatang penyuluhan, komunikasi dan sosialisasi tentang GenRe (Generasi Berencana), strategi pengenalan BKKBN terhadapat generasi muda, maka penelitian ini berfokus pada program yang baru dicanangkan oleh BKKBN yakni program Sekolah Siaga Kependudukan (SSK) sebagai upaya pemerintah (BKKBN) dalam menyokong bonus demografi yang terjadi di Indonesia. Penelitian ini berusaha mengkaji implementasi program Sekolah Siaga Kependudukan, di Kabupaten Gresik hanya terdapat satu sekolah yang ditunjuk untuk menjalankan program pendidikan kependudukan (SSK) yakni Madrasah Aliyah Negeri 1 Gresik. Penelitian ini bertujuan untuk melihat realitas pihak sekolah dalam merespon intruksi yang diberikan pemerintah (BKKBN) untuk menjalankan Pendidikan Kependudukan (SSK).Berangkat dari latar belakang, peneliti dapat merumuskan permasalahan penelitian yakni "Bagaimana 
implementasi kebijakan pendidikan kependudukan melalui Sekolah Siaga Kepndudukan dalam perspektif teori AGIL di Kabupaten Gresik?"

\section{METODE}

Pada penulisan ini, peneliti menggunakan pendekatan kualitatif deskriptif dengan prespektif AGILoleh Talcott parsons sebagai pisau bedah dalam kajian implementasi pendidikan kependudukan dengan program Sekolah Siaga Kependudukan (SSK). Parson sejak lama sudah memberikan kunci keberhasilan dalam mencapai suatu sistem sosial yang baru yakni melalui AGIL, Sekolah Siaga Kependudukan (SSK) dapat tercapai dengan baik jika telah melewati berbagai indicator yang matang dengan sinergitas antar komponen masyarakat yang baik. Miles dan Huberman menyatakan bahwa dalam penelitian kualitatif data yang disajikan bersifat naratif, penelitian kualitatif digunakan untuk menemukan, menyelidiki dan menggambarkan fenomena yang dialami oleh subjek peneliitian(Sugiyono, 2017).

Penelitian ini dilakukan di sekolah Madrasyah Aliyah Negeri 1 Gresik (MAN 1 Gresik), alasan peneliti mengambil lokasi tersebut dikarenakan MAN 1 Gresik merupakan satu satunya sekolah percontohan Sekolah Siaga Kependudukan di Kabupaten Gresik.Penentuan Informan dalam penelitian ini menggunakan teknik Purposive Sampling.Adapun kriteria subjek yang digunakan yakni 1) Para pemangku jabatan yang terlibat dalam pelaksanaan pendidikan kependudukan (SSK) di kabupaten Gresik, 2) Tenaga Pendidik MAN 1 Gresik, 3) Peserta Didik MAN 1 Gresik.

Jenis data dalam penelitian ini yakni data primer dan sekunder.Data primer diperoleh melalui observasi dan wawancara mendalam.Data sekunder di peroleh dari dokumen yang relevan dengan tema penelitian, jurnal, dan buku.Miles dan Huberman menyatakan bahwa dalam penelitian kualitatif data yang disajikan bersifat naratif,Analisis data dalam penelitian kualitatif dilakukan mulai dari awal penelitian. Mulai dari perumusan masalah, saat di lapangan, maupun sesudah di lapangan.Namun dalam penelitian ini, peneliti lebih fokus dalam melakukan analisis data pada saat dan sesudah dilapangan. terdapat langkah-langkah dalam analisis data, diantaranya yakni Reduksi Data, Penyajian Data dan Penarikan Kesimpulan (Moleong, 2006)

\section{HASIL DAN PEMBAHASAN}

\section{Implementasi Pendidikan Kependudukan dalam Sekolah Siaga Kependudukan (SSK)}

Tantangan untuk mewujudkan pembangunan berkelanjutan yakni berbagai isu kependudukan yang saat ini terjadi di masyarakat, seperti halnya kepadatan penduduk, banyaknya usia muda menjadi tantangan tersendiri Negara Indonesia dalam menyiapkan usia muda yang produktif. Karena penyiapan atau pembentukan usia muda produktif menjadi sebuah aset Negara dalam pembangunan jangka panjang, maka dari itu adanya berbagai pihak saling sinergi dalam mengatasi dan mengantisipasi dampak yang ditimbulkan dari isu kependudukan ini, salah satu inovasi strategis yang dicanangkan pemerintah melalui BKKBN dengan meningkatkan peran guru dalam menanamkan pengetahuan, sikap, perilaku yang adaptif mengenai situasi kependudukan saat ini. Menurut Adi Yumanto selaku Kepala Dinas KBPPPA Gresik, Adanya program Sekolah Siaga Kependudukan yang memadukan materi 
kependudukan dalam proses pembelajaran dengan model kearifan lokal akan menciptakan siswa yang memahami dan peduli akan isu isu kependudukan. Madrasah Aliyah Negeri 1 Gresik menjadi sekolah percontohan SSK pertama di kabupaten Gresik. Adapun tujuan pembentukan Sekolah Siaga Kependudukan yakni memupuk kesadaran dan rasa tanggungjawab peserta didik terhadap situasi dan kondisi kependudukan di kabupaten Gresik, hal tersebut dicapai melalui pengembangan sikap dan perilaku peserta didik dalam megambil keputusan untuk mengatasi permasalahan kependudukan yang terjadi.

Pelaksanaan Sekolah Siaga Kependudukan di MAN 1 Gresik memiliki sasaran program dasar yakni 1) Pendewasaan usia perkawinan, 2) Pemahaman Kespro, 3) Pemahaman konsep pembangunan keluarga, 4) mencegah dan memahami angka kematian ibu dan bayi, 5) Meningkatkan kualitas pendidikan di usia produktif. Mewujudkan sasaran tersebut di temukanya prinsip-prinsip dasar dalam pelaksanaannya, Yakni 1) Sekolah Siaga Kependudukan di dalmnya memadukan materi pendidikan kependudukan yang dimasukan dalam mata pelajaran yang sesuai dengan pokok bahasan, seperti halnya pembahasan kesehatan Reproduksi yang dipadukan dengan mata pelajaran Biologi dengan pembahasan yang dipertajam dan terus mengalami pengembangan sesuai kondisi yang terjadi saat ini. 2) Sekolah Siaga Kependudukan mengutamakan peran aktif peserta didik dalam mengamati mengumpulkan, mengolah, dan menganalisis isu kependudukan yang terjadi di tempat tinggal siswa, dengan tujuan menciptakan kesadaran peserta didik untuk bertanggung jawab menemukan solusi permasalahan kependudukan di daerahnya masing-masing.3) Sekolah Siaga Kependudukan menjadi wadah yang sangat efektif bagi remaja di dalam dunia pendidikan. Sekolah Siaga Kependudukan di MAN 1 Gresik juga terdapat pojok kependudukan di dalamnya, pojok kependuduk (population corner) berfungsi sebagai tempat yang menyediakan informasi mengenai materi-materi kependudukan yang ditujukan kepada peserta didik, pojok kependudukan sekaligus dapat simultan denan program yang di canangkan BKKBN seperti PIK R.

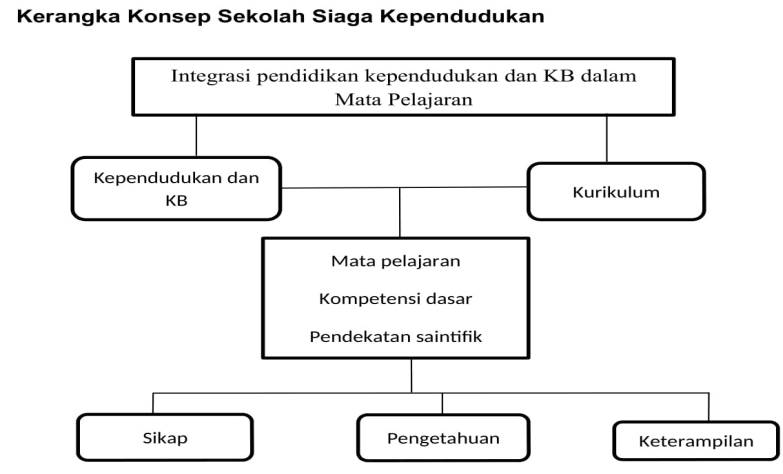

Mekanisme operasaisonal yang dilakukan Guru dalam mengampu mata pelajaran Kependudukan, pertama, menyusun Rencana Pelaksanaan Pembelajaran (RPP) dan Lembar Kerja Siswa, setelah itu Guru melalukan pembelajaran kepada siswa dengan mengenai gambaran isu kependudukan yang terdapat di daerah setempat, Guru menjelaskan mengenai metode penggalian informasi, hal tersebut bertujuan agar siswa secara langsung mengetahui objyek permasalahan yang sedang dihadapi. Data 
yang sudah didapat oleh siswa setelah turun lapangan selanjutnya guru akan menjelaskan mengenai teknik analisis secara sederhana. Guru juga berperan aktif berdiskusi dengan siswa di pojok kependudukan, pojok kependudukan sebagai ruang informasi sekaligus juga sebagai ruang konsultasi. Mekanisme operasional yang dilakukan peserta didik dalam pembelajaran pendidikan kependudukan yakni menyiapkan instrumen untuk penggalian informasi yang akan dikaji, selanjutnya melakukan penggalian data kepada masyarakat sekitar, data yang diperoleh kemudian di analasis dan diskusikan kepada Guru serta di presentasikan kepada teman sekelas.Strategi operasional SSK yakni memberikan pemahaman kepada peserta didik mengenai keluarga kecil yang berkualitas, disisi lain memotivasi peserta didik untuk berpartisipasi dibidang kependudukan. Program SSK diharapkan dapat memperkuat kelembagaan untuk membentuk peserta didik dengan mental spiritual dengan dukungan yang bersifat psikologis. Kita tahu bahwa Indonesia khususnya Jawa Timur sudah atau akan mengahadapi bonus demografi, oleh karena itu kesempatan tersebut harus di peroleh dengan maksimal guna membangun Indonesia yang lebih sejahtera.

\section{Pendidikan Kependudukan (Sekolah Siaga Kependudukan) dalam Momentum Bonus Demografi.}

Bermacam-macam isu kependudukan menjadi suatu tantangan dan ancaman dalam pembangunan berkelanjutan, untuk itu dalam mengatisipasi dan mengatasi diperlukanya sinergi anatar berbagai pihak.Mulai dari pemerintah, sektor pendidikan dan lemabaga lainya. Pendidikan kependudukan sebagai upaya yang terencana untuk membantu memberikan pemahaman kepada masyarakat tentang kondisi kependudukan yang terjadi saat ini, pembentukan Sekolah Siaga Kependudukan merupakan salah satu upaya pemerintah dalam menyikapi akan berlansungnya bonus demografi yang terjadi di Indonesia pada tahun 2020 sampai 2035. Kabupaten Gresik saat ini mencoba merintis Sekolah Siaga Kependudukan, sekolah yang menjadi rintisan program pendidikan kependudukan yakni MAN 1 Gresik. Adapun alur pelaksanaan Sekolah Siaga Kependudukan sebagai berikut.

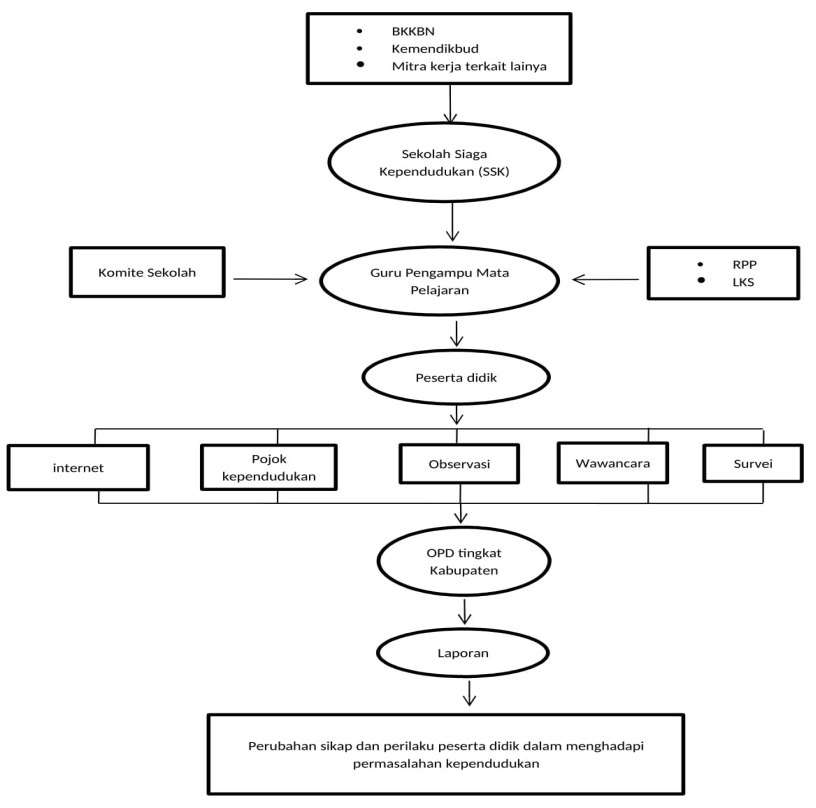


Melaui Sekolah Siaga Kependudukan mampu memberikan sumbangsih dalam pembangunan SDM remaja, program pendidikan kependudukan diarahkan untuk membentuk remaja berkarakter yang bertanggung jawab dan selalu berperilaku sehat.Remaja yang baik akan menjadi role model dalam sebuah masyarakat. Output dari dirintisnya sekolah siaga kependudukan di MAN 1 Gresik yakni meberikan pemahaman Kesehatan Reproduksi (Kespro) dan Pendewasaan Usia Perkawinan (PUP) dapat tertanam di diri peserta didik dan bisa mempengaruhinya dalam merencanakan masa depanya, minimal meningkatkan usia perkawinan sebagaimana telah di tetapkan BKKBN bahwa usia ideal menikah yakni 25 tahun untuk laki-laki dan 21 tahun untuk perempuan. Dengan adanya pemahaman tersebut diharapkan mampu memberikan andil dalam menyukseskan bonus demografi, karena dalam menyukseskan bonus demografi diperlukanya SDM yang berkualitas dan berkarakter.

\section{Sekolah Siaga Kependudukan dalam Prespektik Struktural Fungsional}

Pendidikan pada dasarnya memiliki peranan penting dalam menyiapkan SDM yang berkualitas, upaya mewujudkan generasi muda yang berkualitas dan mampu berfikir kritis mengenai isu isu kependudukan dengan merintis Sekolah Siaga Kependudukan.Tulisan mencoba mengkaji implementasi Sekolah Siaga Kependudukan dengan konsep teori strukrural fungsional Talcoot Parsons. Pokok pikiran parsons dalam perekmbangan pada tahun 1950 dalam bukunta "The Sosial System" yang di terbitkan tahun 1951 tentang konsep AGIL yang merupakan pengembangan teori fungsionalisme structural, konsep tersebut mengemukakan 4 prasyarat mutlak yang harus dicukupi oleh setiap masyarakat, kelompok atau organisasi. Bila ke 4 prasyarat tidak dicukupi, maka sistem sosial tersebut tidak akan dapat bertahan dan harus berakhir, 4 konsep tersebut yakni Adaptation, Goal Atainment, Integration dan Latency, atau yang bisa kenal dengan konsep AGIL(George Ritzer, 2010). Menurut parsons keempat fungsi tersebut masuk dalam sistem tindakan, Pertama Adaptation, adalah konsep agar masyarakat dapat bertahan maka mereka harus mampu menyesuaikan diri, Kedua Goal (tujuan) adalah sistem diterapkan harus mampu menentukan suatu tujuan dan tujuan tersebut harus sesuai dengan kebutuhan, Ketiga Integration, pada tahap ini masyarakat diharuskan untuk bekerja sama dengan komponen masyarakat lainya (pemerintah, swasta, masyarakat itu sendiri dsb), Keempat, Letency, langkah selanjutnya masyarakat harus mempertahankan nilai dasar serta norma yang disepakati bersama (Maunah, 2015).

Pertama, Adaptation, Dari teori struktural fungsional diatas, implementasi Sekolah Siaga Kependudukan di MAN 1 Gresik memiliki ketahanan yang kuat, hal tersebut bisa dilihat dari struktur dan sistem lemabaga dalam menghadapi tantangan akan peluang menuju pendidikan kependudukan yang baik sesuai kondisi yang dibutuhkan saat ini untuk mencapai peluang bonus demografi. Sistem adapatsi yang dilakukan di MAN 1 Gresik sebagai rintisan Sekolah Siaga Kependudukan sangat jelas, ketika melihat fungsi dari Sekolah Siaga Kependudukan yang memposisikan sebagai pendidikan kependudukan dengan memadukan pendidikan yang ada di MAN 1 Gresik yang dominan akan budaya islaminya. Perpaduan tersebut menjadi suatu bekal dalam proses pembangunan dan perubahan sosial sehingga terbentuknya remaja yang berkarakter dan peduli akan kependudukan.AdaptasiPara tenaga didik dan peserta didik 
tidak mengalami kesulitan yang cukup berarti,karena Sekolah Siaga Kependudukan memadukan antara pelajaran umum, agama yang di integrasikan dengan materi kependudukan. Karena pada dasarnya Sekolah Siaga Kependudukan bukan mata pelajaran baru, tidak menambah jam pelajaran, dan mempertajam materi yang dibahas akan kondisi kependudukan saat ini. Hal tersebut membuat para tenaga didik dan peserta didik menagalami kemudahan beradaptasi dengan dirintisnya Sekolah Siaga Kependudukan.Dilain sisi terdapatnya Pojok Kependudukan menajadi wadah diskusi antara peserta didik dan tenaga pendidik dalam membahas permasalahan kependudukan serta mencari solusi untuk mengatasinya. Hal tersebut membuat peserta didik mempunyai banyak informasi dan peduli akan isu isu kependudukan yang terjadi disekitarnya.

Kedua, Tujuan (goal attainment), Sistem pendidikan kependudukan (SSK) mempunyai tujuan (goal attainment) yang sangat jelas.Secara khusus tujuan dari Sekolah Siaga Kependudukan yang pertama yakni menumbuhkan peserta didik yang sadar dan tanggung jawab terhadap kondisi kependudukan yang ada disekitarnya, kedua, pendidikan kependudukan dapat mengembangkan sikap dan perilaku peserta didik dalam menghadapi permasalahan dan dapat mengambil keputusan untuk mengatasi permasalahan kependudukan. Sekolah Siaga Kependudukan menyasar mengenai isu kependudukan dengan memberikan pemahaman akan pentingnya kesehatan reproduksi kepada remaja, dan juga memberikan pemahaman mengenai Pendewasaan Usia Perkawinan (PUP), serta memberikan konsep membangun keluarga yang berkualitas. Adanya pendidikan kependudukan ini diharapkan mampu meningkatkan kualitas remaja di usia produktif untuk turut serta berperan aktif dalam meamanfaatkan bonus demografi yang sedang terjadi dan akan terjadi di Indonesia.

Ketiga, integration, Pelaksanaan sistem Sekolah Siaga Kependudukan memerlukan integration antara komponen-komponen yang terdapat didalamnya sehingga terbentuknya kesatuan, program SSK merupakan pencanangan BKKBN yang menyasar pada remaja. Melalui pendidikan formal yang berjenjang, dimulai dari pendidikan dasar, pendidikan menengah, pendidikan menengah atas dan pendidikan tinggi.Mulai dirintisnya SSK melibatkan banyak pihak tekait, mulai dari pemerintah pusat (BKKBN, Kemendikbud), OPD tingkat Kabupaten Gresik, Komite Sekolah, Tenaga Pendidik, dan Peserta didik.Integrasi yang dilakukan antara beberapa pihak sudah dilakukan, baik secara kurikulum maupun kelembagaan. Mulai dari penyampaian workshop yang dilakukan oleh OPD kabupaten yakni dinas KBPPPA Gresik dengan tema pengenalan SSK kepada tenaga pendidik dan peserta didik pada mas orientasi siswa baru. Hal tersebut menunjukan adanya sinergi antara komponen yang ada didalamnya, karena integrasi ini sangat penting , satu sama lain saling mempengaruhi, tanpa adanya integrasi maka tujuan Sekolah Siaga Kependudukan akan menjadi boomerang.Oleh karena itu kebijakan Pemerintah Kabupaten diharapkan konsisten dalam mengimplementasikan Sekolah Siaga Kependudukan serta partisipasi semua unsur, mulai dari pemegang kepentingan dan sesluruh warga MAN 1 Gresik.

Keempat, Pemeliharaan pola (latency), mempertahankan nilai dasar dan norma yang telah disepakati bersama dalam Sekolah Siaga Kependudukan sangatlah penting.Program Sekolah Siaga Kependudukan ini akan konsisiten selama materi yang berhubungan dengan kependudukan tetap ada dalam kurikulum yang diajarkan. 
Pendidikan kependudukan berpegang pada nilai-nilai karakter peserta didik sehingga dapat memberikan sumbangsih yang berarti untuk membangun nilai dan moral pada individu yang berkarakter di tengah masyarakat, seperti sifat sadar kependudukan, peduli terhadap sesama, dan toleransi antar sesama.Sistem nilai tersebut harus dipertahankan dalam sistem pendidikan kependudukan (SSK) dan mempertahankan komponen-komponen yang dimiliki seperti halnya menjadikan Pojok Kampung sebagai tempat pemberian informasi dan sebagai sarana diskusi mengenai isu kependudukan. Pendidikan kependudukan melalui Sekolah Siaga Kependudukan merupakan sistem sosial yang pada tahun 2018 sudah dicanangkan pemerintah dan dirintis di MAN 1 Gresik pada tahun 2020 untuk menciptakan remaja yang paham dan sadar akan isu kependudukan disekitarnya. Parson sejak dulu telah memberikan kunci dalam keberhasilan mencapai sebuah sistem sosial yang baru yakni melalui konsep AGIL.Ketahanan pendidikan kependudukan harus dipahami secara mendalam, Pendidikan kependudukan (SSK) memiliki ketahanan dan kontinuitas apabila melakukan 4 kosep sistem diatas yang dicetus oleh parsons. Jika tidak maka dapat dipastikan pendidikan kependudukan tidak akan berjalan dan lebih ke pendidikan secara umum.

\section{SIMPULAN DAN SARAN}

Generasi muda yang berkualitas mempunyai peluang sebagai penerus bangsa untuk membangun bangsa yang lebih baik lagi, terbentuknya kepedulian dan kesadaran terhadap isu kependudukan berdampak pada tumbuhnya rasa rasa tanggungjawab untuk ikut serta mencegah dan ikut serta mencari solusi dalam mengatasi permasalahan kependudukan. Maka dari itu dengan adanya Sekolah Siaga Kependudukan diharapkan mampu membentuk karakter remaja akan sadar isu isu yang terjadi dalam penduduk dan ikut serta berpartisipasi dalam menyelesaikan permasalahan kependudukan. Sekolah Siaga Kependudukan merupakan sekolah yang mengintegrasikan pendidikan kependudukan dan keluarga berencana ke dalam beberapa mata pelajaran sebagai pengayaan materi pembelajaran, terdapat pojok kependudukan di dalamnya. Mengimplementasikan kebijakan pendidikan memelurkan empat syarat sistem yang harus dipenuhi agardapat berjalan dengan baik. Bila ke empat prasyarat tidak dicukupi, maka sistem sosial tersebut tidak akan dapat bertahan dan harus berakhir, empat konsep tersebut yakni Adaptation, Goal Atainment, Integration dan Latency, atau yang bisa kenal dengan konsep AGIL.

Berdasarkan hasil temuan dalam penelitian, disarankan dalam menjalankan Sekolah Siaga Kependudukan harus saling memperkuat peran kepemimpinan dalam mengelola, dan sinergi antara pihak terkait harus diperkuat lagi, mulai dari komunikasi anatara OPD kabupaten dengan pihak sekolah. Serta perlu adanya jaringan masyarakat yang turut dilibatkan dalam menyukseskan sekolah siaga kependudukan.Memaksimalkan peran peran media sosial dalam membranding semua kegiatan yang terdapat SSK, sehingga dapat menjadi inspirasi bagi sekolah-sekolah untuk menjadi Sekolah Siaga Kependudukan. Latency atau pemeliharan pola yang didalamnya terdapat norma harus tetap dijalankan dan dipatuhi secara baik. 


\section{DAFTAR PUSTAKA}

Aritonang, V. (2017). JOM FISIP Vol. 4 No. 2 - Oktober 2017 Page 1. Strategi Bertahan Hidup Petani Penggarap Di Jorong Sarilamak Nagari Sarilamak Kecamatan Harau Kabupaten Lima Puluh Kota, 4(1), 1-13.

Badan Perencanaan Daerah Jawa Timur. (2019). Data Dinamis Provinsi Jawa Timur: Triwulan II 2018. Journal of Chemical Information and Modeling, 53(9), 1689-1699.

BPS. (2017). Indeks Pembangunan Manusia. Bps, 16, 55. https://sirusa.bps.go.id/sirusa/index.php/indikator/763

Erlangga, A. (2019). MINI SURVEI:Pemanfaatan Media Promosi Pendidikan Kependudukan Bagi Remaja Sebagai Acuan Peningkatan Media Komunikasi Informasi Edukasi (KIE) Pendidikan Kependudukan. BKKBN.

Fernandes, R. (2017). Adaptasi Sekolah Terhadap Kebijakan Pendidikan Inklusif. Jurnal Socius: Journal of Sociology Research and Education, Vol. 4 (2).

George Ritzer, D. J. G. (2010). Teori Sosiologi Modern. Kencana.

Maunah, B. (2015). Pendidikan Dalam Perspektif Struktural Konflik. CENDEKIA: Journal of Education and Teaching, 9(1), 71. https://doi.org/10.30957/cendekia.v9i1.53

Mayasari, S., \& Husin, A. (2014). Remaja Genre: Peluang Menuju Bonus Demografi. Demography Journal of Sriwijaya, 1(2), 4-8. https://www.neliti.com/publications/181646/remaja-genre-peluang-menuju-bonusdemografi

Moleong, J. (2006). Metode Penelitian Kualitatif Edisi Revisi. PT. Remaja Rosdakarya. Mukri, S. G. (2018). Menyongsong Bonus Demografi Indonesia. Buletin Hukum \& Keadilan, 2(6), 51-52.

Noor, M. (2015). Kebijakan Pembangunan Kependudukan dan Bonus Demografi. Serat Acitya-Jurnal IImiah, 4(1), 121-128.

Pamungkas, M. A. (2017). Milenium Development Goals Dalam Rangka Menanggulangi Kemiskinan di Yogyakarta. 20150520132, 1-9.

Sari, V. I., \& Indrawadi, J. (2019). Pembentukan Karakter Remaja Kota Padang Melalui Program Generasi Berencana untuk Menghadapi Bonus Demografi 2030. Journal of Civic Education, 2(4), 283-294. https://doi.org/10.24036/jce.v2i4.254

Sugiyono. (2017). Metodologi Penelitian Kuantitatif, Kualitatif dan R\&D. Alfabeta.

Susanti, H. A. (2015). Strategi Komunikasi Badan Kependudukan dan Keluarga Berencana Nasional (BKKBN). Jurnal ASPIKOM, 2(4), 243. https://doi.org/10.24329/aspikom.v2i4.75

Utami, D. D. Y. (2015). Penyuluhan Program BKKBN Mengenai Generasi Berencana ( GenRe ) dan Sikap Remaja. Jurnal Simbolika, 1(2), 199-210.

Yulianti, D. (2017). Program Generasi Berencana (GenRe) Dalam Rangka Pembangunan Manusia Menuju Pembangunan Nasional Berkualitas. Jurnal Analisis Sosial Politik, 1(2), 93-108. 